\title{
DINAMIKA HUKUM DAN EKONOMI \\ DALAM REALITAS SOSIAL DI INDONESIA \\ (STUDI KRITIS TERHADAP KEBIJAKAN HUKUM - EKONOMI DI INDONESIA)
}

(Law and Economic Dynamics in Social Reality in Indonesia)

(Critical Study on Legal - Economy Policies in Indonesia)

\author{
Muhammad Rusydianta \\ Universitas Darussalam Gontor \\ Jl. Raya Siman Km 06, Siman, Ponorogo, Jawa Timur, 64371 \\ Email: rusydianta@gmail.com
}

Naskah diterima: 19 Agustus 2017; revisi: 13 November 2017; disetujui: 20 November 2017

\begin{abstract}
Abstrak
Fenomena runtuhnya sistem sosialis di Uni Soviet juga berpengaruh pada dinamika antara hukum dan ekonomi yang terjadi di Indonesia, berbagai kebijakan yang muncul menjelang runtuhnya Uni Soviet mirip dengan berbagai kebijakan yang terapkan di Indonesia. Dalam penelitian dokumenter jenis sociological jurisprudence ini hendak menjawab bagaimana dinamika antara hukum dan ekonomi yang terjadi di Indonesia? Apakah sistem hukum dan perundang-undangan yang berlaku di suatu negara cenderung memfasilitasi sistem dan pola perekonomian tertentu? Dengan pendekatan kasus, pendekatan historis, pendekatan perundang-undangan, pendekatan kebijakan dan pendekatan konseptual dapat disimpulkan, bahwa dinamika antara hukum dan ekonomi yang tengah terjadi di Indonesia selalu tergambar dan tercermin dalam determinasi ekonomi atas hukum dan sebaliknya. Peraturan perundang-undangan Indonesia memang cenderung memfasilitasi sistem dan pola perekonomian tertentu, bahkan cenderung tunduk pada sistem perekonomian yang ada. Dan tidak dapat dipungkiri bahwa determinasi ekonomi atas hukum lebih merusak sistem sosial kemasyarakatan dari pada determinasi hukum atas ekonomi. Kecuali berbagai kebijakan sosial di bidang hukum dan ekonomi dikembalikan kepada nilai-nilai yang terkandung dalam Pancasila, dan didasarkan atas konstitusi dalam upaya mencapai welfare state.
\end{abstract}

Kata Kunci: dinamika, determinasi, ekonomi, hukum, sosial

\begin{abstract}
Looking at the various phenomenon that occurred since the end of World War 2 with the emergence of the Western and Eastern Bloc, the collapse of the socialist system and the Soviet Union, and so on. As a developing country, due to the dynamics of law and economics in Indonesia, the various policy characteristics that emerged before the collapse of the Soviet Union are similar to the various policies applied in Indonesia, so there is an urgent need to cope so as not to happen. In this type of sociological jurisprudence documentary research, several approaches are used to examine various research data derived from primary, secondary and tertiary data sources. These approaches include case approach, historical approach, legislation approach, policy approach and conceptual approach. Based on data and facts can be concluded, that the dynamics of law and the economy that is happening in Indonesia is always reflected and reflected in the economic determination of the law and vice versa. Where Indonesian legislation does tend to facilitate certain economic systems and patterns, even tending to the existing economic system. And in Indonesia it can not be denied that the economic determination of the law is more damaging to the social system than the legal determination of the economy. Unless the various social policies in the law and economics field are returned to the values contained in Pancasila and based on the constitution in order to achieve the welfare state.
\end{abstract}

Keywords: dynamics, determination, economy, law, social 


\section{A. Pendahuluan}

Sejarah new imperialism abad 21 dimulai dari tahun 1945 dengan menyerahnya Jepang kepada sekutu yang menandai berakhirnya Perang Dunia ke-2. Menanggapi kerugian materil senilai trilyunan (USD) dolar maupun kerugian immaterial berupa korban tewas di kisaran angka \pm 62-78 juta jiwa dari pihak sipil dan militer selama peperangan berlangsung. ${ }^{1}$ Bagi pihak yang menang, selesainya perang justru telah menimbulkan peperangan baru memperebutkan pengaruh dan kekuasaan guna menutupi kerugian materil immateril akibat perang, yang kemudian membagi dunia menjadi dua poros kekuatan, antara Blok Barat dan Blok Timur, antara Sekutu dan Uni Soviet, antara kapitalis dan sosialis. Perang Dingin atau Cold War, demikian istilah ini disebut di kemudian hari. Meskipun tidak memicu perang terbuka, namun dampak dan akibat dari situasi ini telah menimbulkan perlombaan serta memunculkan persaingan baru dalam segala bidang, khususnya yang terkait dengan bidang ekonomi, politik, hukum dan militer. ${ }^{2}$ Akan tetapi, sejak runtuhnya Uni Soviet sebagai poros blok timur sosialis pada tahun 1991. Kekosongan sistem dan kekuasaan tersebut segera dimanfaatkan dengan baik oleh blok barat kapitalis untuk segera menguasai sistem politik dan perekonomian dunia, dari sinilah barat dengan ekonomi kapitalis yang dicetuskan oleh Adam Smith dalam bukunya "The wealth of nation" mulai mendominasi. ${ }^{3}$

Dalam perkembangan ekonomi dan pembangunan global istilah "Barat" sendiri seakan sudah tidak lagi merujuk pada barat sebagai letak geografis atau sekedar penunjuk arah dalam jarum kompas, melainkan telah menjadi istilah tersendiri. Karena mereka yang terletak berdampingan dengan negara adidaya sebagai pusat peradaban barat lebih diasumsikan sebagai negara atau wilayah tersendiri dengan istilah "Negara Dunia Ketiga," "Negara Berkembang," "Amerika Latin," dan lain-lain. Justru Australia yang secara astronomis geografis terletak di tepi Samudra Hindia, selatan Indonesia dalam pengertiannya termasuk dalam kategori negara barat. Oleh sebab itu, kategorisasi istilah negara "Barat" telah mengalami pergeseran dan lebih condong

Sebagai contoh, selama Perang Dunia ke-II Amerika Serikat telah menghabiskan 108 milyar US Dollar hanya untuk mobilisasi perang. Kemudian dari kerugian immateril, korban tewas di benua Eropa saja mencapai 39 juta jiwa dan total korban diperkirakan 3\% dari total penduduk dunia atau pada estimasi 62 hingga 78 juta korban tewas dari 2 milyar penduduk dunia ketika itu. Taylor Jaworski and Price V. Fishback, World War II [Prepared for the Oxford Handbook of American Economic History], March (2014): 1, 7. Lihat juga Iris Kesternich, Bettina Siflinger, James P. Smith, and Joachim K. Winter, "The Effects of World War II on Economic and Health Outcomes across Europe," RAND Labor and Population Working Paper Series, January 22, (2012): 1, or "The Effects of World War II on Economic and Health Outcomes across Europe," www.mitpressjournals.org, Vol. 96, No. 1, March (2014): 103-118.

2 Susan J. Linz, World War II and Soviet Economic Growth 1940-1953, Faculty Working Paper No. 1038, Bureau of Economics and Businnes Research (BEBR),University of Illinois, May (1984): 36-37.

3 Sejarah mencatat Adam Smith sebagai peletak dasar pemikiran kapitalisme yang didasarkan pada postulasi, bahwa "Bekerjanya mekanisme hukum pasar didasarkan atas dasar dorongan kepentingan-kepentingan pribadi karena kompetisi dan kekuatan individualisme dalam menciptakan keteraturan ekonomi." Eko Prasetyo, Kapitalisme \& Neoliberalisme; Sebuah Tinjauan Singkat, Ekonomi Politik Journal Al-Manär, Edisi I (2004): 2. 
pada persamaan sistem, sosial, hukum, politik dan ekonomi sebagai kriteria standar. ${ }^{4}$

Sejarah mencatat, bahwa runtuhnya sistem sosialis dan pecahnya Uni Soviet disebabkan dan tidak lain bermula dari masalah ekonomi yang membawa efek domino bagi kestabilan sosial politik. Sehingga berdampak pada merosotnya sistem hukum yang berlaku serta merobohkan sendi-sendi kenegaraan yang berakibat pada pecahnya Uni Soviet menjadi beberapa Negara seperti Yugoslavia, Tajikistan, Afganistan, Uzbekistan, Turkmenistan dan lainnya. Uni Soviet sebagai negara multi etnis, ${ }^{5}$ dalam sejarah panjang runtuhnya, diguncang oleh masalah struktural berkepanjangan yang diakibatkan dari konflik dan kesenjangan sosial ekonomi yang tinggi akibat dari kebijakan pemerintah terkait kebijakan perestroika (restrukturisasi ekonomi) pada tahun 1985 yang dinilai bersifat diskriminatif, disamping kebijakan lain seperti glasnost (keterbukaan politik), dan uskoreniye (percepatan pembangunan ekonomi) yang di kemudian hari memberikan celah untuk pembubaran dan melepaskan diri dari Uni Soviet. ${ }^{6}$

Dengan runtuhnya sosialis Uni Soviet, dunia seakan telah memasuki era imperialisme baru yang berkiblat dan dipengaruhi oleh poros kapitalis barat yang terkenal dengan westernisasi dalam berbagai bidang, khususnya ekonomi, budaya, ilmu pengetahuan dan tekhnologi (Iptek), sosial politik bahkan dalam bidang hukum. ${ }^{7}$ Mulai dari sini westernisasi seakan menjadi an influence pandemic baru yang menular ke seluruh kawasan dunia. Dalam bidang kebudayaan sudah tidak asing lagi bila melihat gaya hidup hedonisme barat yang serba praktis dan konsumtif terintegrasi dengan baik di kehidupan rakyat Indonesia sehari-hari sehingga menjadi standar hidup dan status sosial

4 Michael P. Todaro dalam bukunya “Economic Developmentin the Third World $4^{\text {th" }}$, secara tidak langsung menjelaskan kriteria "Negara Barat" sebagai kebalikan dari kriteria yang ia sebutkan sebagai ciri umum negara berkembang yaitu: 1. standar hidup yang rendah, 2. produktifitas yang rendah, 3. tingkat pertumbuhan penduduk dan beban ketergantungan yang tinggi, 4. tingkat pengangguran tinggi yang cenderung meningkat disertai kekurangan pekerjaan, 5. sangat tergantung pada produksi pertanian dan barang ekspor, 6. dominasi, ketergantungan dan kepekaan yang besar dalam hubungan internasional. Michael P. Todaro, Economic Development in the Third World, diterjemahkan oleh Burhanuddin Abdullah dan Harris Munandar, Cet. II (Surabaya: Penerbit Erlangga, 1989), hlm. 28.

5 Sebagaimana yang dikutip oleh Paul E.. Lyndolp, jumlah suku-etnis di USSR mencapai 22 etnis. Lihat Paul E. Lyndolp, Geography of the U.S.S.R. 5th Ed. Elkhart Lake. (Wiscosin: Misty Valley Publishing, 1990), hlm. 89, namun berdasarkan data yang dirilis oleh U.S. Bureau of the Census dalam USA-USSR facts and figure jumlah etnis yang tercatat secara de jure berjumlah \pm 98 etnis. Lihat U.S. Bureau of the Census, USA/USSR: Facts and Figures, (Washington, DC: U.S. Government Printing Office, 1991), hlm. 4-5.

$6 \quad$ Ketidakstabilan sistem sosialis dalam menanggapi masalah sosial-ekonomi antara tahun 1982-1985 telah mendorong pemimpin Uni Soviet Mikhail Gorbachev untuk mengintegrasikan sistem demokrasi ke dalam sistem autokrasi Uni Soviet untuk meningkatkan perekonomian negara dengan menerapkan kebijakan perestroika (restrukturisasi ekonomi), glasnost (keterbukaan politik), dan uskoreniye (percepatan pembangunan ekonomi). Kathryn Stoner Weiss and Michael Mcfaul, Domestic and International Influences on the Collapse of the Soviet Union (1991) and Russia's Initial Transition to Democracy (1993), Cddrl Stanford Working Papers, Number: 108, Center On Democracy, Development, and The Rule of Law. Freeman Spogli Institute for International Studies, March (2009): 4-6.

7 Dari sekian banyak negara yang merdeka dari penjajahan, produk maupun corak hukum negara tersebut cenderung mengikuti corak-produk hukum negara yang menjajah mereka, seperti negara Indonesia yang bercorak hukum Belanda-Civil Law maupun Malaysia dan India yang bercorak Inggris-Anglo Saxon. Contoh sistem ialah sistem hukum Indonesia yang menganut civil law dan produk hukum ialah KUHP Indonesia yang merupakan warisan KUHP pemerintah Hindia Belanda yang direvisi. Lihat dasar pertimbangan dalam UU No. 73 Tahun 1958 tentang Pemberlakuan UU No. 1 Tahun 1946 tentang KUHP. 
ekonomi masyarakat yang kadang mereduksi arti makna dari kata "sosial" itu sendiri. Dalam bidang keilmuan akademik tidaklah aneh bila menemukan realitas unsur keterpaksaan dalam menggunakan bahasa asing dibandingkan dengan penggunaan bahasa ibu karena tuntutan global seolah mengharuskan hal tersebut. Westernisasi di bidang teknologi dan informasi dapat dilihat dari perkembangan teknologi dan informasi sehari-hari di mana di setiap detikmenit-jam-hari selalu ada terobosan baru dalam kedua bidang tersebut. Sehingga dulu handphone merupakan barang ekslusif, kini sudah dapat ditemukan di genggaman anak TK sekali pun. Keterbatasan jarak dan waktu yang dahulu menjadi jurang pemisah, kini dengan adanya teknologi sedikit demi sedikit telah mengisi jurang pemisah tersebut.

Dengan demikian, segala kemajuan di bidang keilmuan, teknologi dan informasi yang dimotori oleh sistem ekonomi kapitalis secara langsung maupun tidak langsung telah mempengaruhi kebudayaan negeri timur, sehingga secara tidak langsung akan merubah dan menggantikan sistem sosial, ekonomi, politik dan kebudayaan yang ada, termasuk sistem hukum yang berlaku di suatu negara tertentu dengan pola, sistem dan kebudayaan tertentu. Maka tidaklah mengherankan bila sistem hukum dan peraturan perundang-undangan yang berlaku di negara tertentu cenderung memfasilitasi sistem dan pola perekonomian tertentu bahkan cenderung tunduk pada sistem perekonomian yang ada. Seperti halnya China yang dahulu berhaluan sosialis dan berkiblat pada Uni Soviet, setelah melihat kegagalan sistem ekonomi Sosialis, maka tidak heran bila melihat fenomena China sebagai negara dengan sistem pemerintahan sosialis, tengah giat dengan Asean China Free Trade Area (ACFTA) nya yang berhaluan kapitalisme global, yang berarti mengadopsi sistem pola perekonomian kapitalisme barat ke dalam sistem perekonomian mereka.

Apabila berkaca pada runtutan fenomena di atas terkait Uni Soviet, Indonesia memiliki kesamaan dalam berbagai segi. Indonesia sebagai negara multi etnis dengan 633 suku besar dari 1331 kategori suku. ${ }^{8}$ Terkait kebijakan pembangunan ekonomi sejak peralihan pemerintahan dari Presiden Soekarno ke Presiden Soeharto sangat erat kaitannya dengan peralihan darisistem ekonomisosialis kerakyatan ke sistem ekonomi kapitalis yang berpengaruh pada arah dan corak kebijakan pemerintahan selanjutnya. ${ }^{9}$ Pengaruh yang berdampak hingga pemerintahan Presiden Jokowi tersebut di mulai dari masa Presiden Soeharto yang menerapkan kebijakan Pembangunan Lima Tahun (Pelita) I-VI 1969-1999 yang mirip dengan kebijakan Uni Soviet terkait perestroika (restrukturisasi ekonomi) dan uskoreniye (percepatan pembangunan ekonomi), yang dampaknya pada zaman sekarang menimbulkan kesenjangan sosial ekonomi yang tinggi disusul dengan berbagai masalah struktural yang merobohkan sendi-sendi kenegaraan terkait pemekaran daerah-otonomi daerah melalui UU No. 22 Tahun 1999 dan UU No. 32 Tahun 2004 tentang

http://www.bps.go.id/kegiatanlain/view/id/127, (diakses 13 November 2017).

9 Supriyanto, Memahami Cara Bekerja Sistem Perekonomian, Jurnal Ekonomi \& Pendidikan, Vol.6 No. 2, November (2009): 193. 
Pemerintahan Daerah yang diganti dengan UU No. 23 Tahun 2014 karena dinilai gagal, ${ }^{10}$ perlawanan serta konflik di daerah otonomi khusus, $^{11}$ masalah kenegaraan mengenai korupsi yang semakin merajalela sejak orde baru hingga era reformasi dan lainnya. Hal ini secara tidak langsung diperparah dengan kebebasan pers yang berlebihan dari masa reformasi yang cenderung merusak setelah diberlakukannya UU No. 9 Tahun 1998 tentang Kemerdekaan Menyampaikan Pendapat di Muka Umum, di mana mirip dengan demokratisasi glasnot (keterbukaan politik) ala Uni Soviet karena menguak masalah-masalah struktural ke publik yang cenderung menimbulkan disintegrasi bangsa.

Selain itu dalam era globalisasi dunia, berkaca pada China yang terkena dampak globalisasi, melihat realitas sehari-hari yang terjadi di Indonesia tidak salah lagi bahwa Indonesia juga telah terkena dampak dari kapitalisme global sejak pemerintahan Presiden Soeharto dengan sistem perekonomian Indonesia yang bercorak neo liberal. Akibatnya dampak yang berakibat pada pecahnya Uni Soviet mulai terasa di Indonesia, hal ini terlihat pada merosotnya sistem hukum yang berlaku serta robohnya sendi-sendi kenegaraan. Dari sini peneliti sebagai civitas akademik di bidang ilmu hukum memandang masalah mengenai dinamika ekonomi dan hukum terkait pengaruh sistem ekonomi terhadap sistem hukum dan produk peraturan perundang-undangan di suatu negara sebagai masalah yang urgent untuk diteliti dan ditemukan solusi penyelesaiannya mengingat kejadian seperti Uni Soviet dapat terulang kembali di Indonesia. Maka merujuk ke Indonesia dalam perumusan masalah ini, bagaimanakah dinamika antara hukum dan ekonomi yang terjadi di Indonesia? Benarkah sistem hukum dan peraturan perundangundangan yang berlaku di suatu negara cenderung memfasilitasi sistem dan pola perekonomian tertentu bahkan tunduk pada sistem perekonomian yang ada?

Merujuk pada rumusan masalah, maka tujuan dari diadakannya penelitian ini, ialah guna mengetahui bagaimanakah dinamika antara hukum dan ekonomi yang terjadi di Indonesia serta untuk mengetahui kebenaran tentang sistem hukum dan peraturan perundang-undangan yang berlaku di suatu negara yang cenderung memfasilitasi sistem dan pola perekonomian tertentu bahkan tunduk pada sistem perekonomian yang ada serta mengetahui bagaimana hal tersebut dapat terjadi.

10 Bukti identifikasi kegagalan otonomi daerah yang merobohkan sendi-sendi kenegaraan , antara lain: 1. Konflik dengan kekerasan. Salah satu contoh kasusnya adalah Kabupaten Polewali-Mamasa yang dimekarkan pada tahun 2002 menjadi Kabupaten Polewali; 2. Menurunnya jumlah penduduk dan PAD secara drastis; 3. Menyempitnya luas wilayah dan beban daerah induk.; 4. Perebutan wilayah dan masalah ibukota pemekaran.; 5. Perebutan asset. Kasus ini pernah terjadi di Kabupaten Nunukan; 6. Menimbulkan potensi masalah pada munculnya pengakuan daerah penghasil.; 7. Kebijakan pembentukan daerah otonom baru belum memberikan dampak yang signifikan bagi perwujudan kesejahteraan masyarakat, pelayanan publik, dan daya saing daerah, baik kepada daerah otonom baru maupun kepada daerah induk, dan lainnya. Lihat Tri Ratnawati, Satu Dasa Warsa Pemekaran Daerah Era Reformasi: Kegagalan Otonomi Daerah?, Jurnal Ilmu Politik, Edisi 21, (2010), hlm. 132-138.

11 http://regional.kompas.com/read/2017/11/09/16473271/kelompok-bersenjata-di-papua-intimidasi-danrampas-harta-warga, (diakses 13 November 2017). 


\section{B. Metode Penelitian}

Penelitian ini merupakan penelitian sosio legal, yang mengkaji tidak sebatas teks, termauk pula di dalamnya pendalaman terhadap konteks, yang mencakup segala proses, misal sedari 'law making' (pembentukan hukum) hingga 'implementation of law' (bekerjanya hukum). ${ }^{12}$ Pendalaman tersebut digunakan untuk mengamati bagaimana reaksi dan interaksi antara hukum dan ekonomi, peneliti menggunakaan berbagai pendekatan, antara lain pendekatan kasus, pendekatan historis, pendekatan peraturan perundang-undangan, pendekatan kebijakan dan pendekatan konseptual. Pendekatan peraturan perundangundangan dilakukan untuk menelaah dan menganalisa regulasi yang berkaitan dengan objek penelitian dan pendekatan historis kasus serta pendekatan kebijakan digunakan untuk memahami, membuktikan dan menyimpulkan perkembangan realitas tentang objek penelitian yang terjadi dari waktu ke waktu. Sedangkan pendekatan konseptual digunakan untuk membangun suatu konsep yang dijadikan sebagai acuan penelitian. ${ }^{13}$ Pada penelitian ini pendekatan-pendekatan tersebut digunakan untuk menelaah berbagai data penelitian yang berasal dari peraturan perundang-undangan sebagai sumber data primer serta buku, jurnal, artikel dan literatur lainnya terkait dengan objek penelitian sebagai sumber data sekunder dan tersier.

\section{Pembahasan}

Indonesia sebagai Negara anggota G-20 sangatlah lekat dengan ciri umum sebagai negara berkembang seperti yang dirumuskan oleh Michael P. Todaro, antara lain:

"1.Standarhidupyang rendah;2. Produksifitas yang rendah; 3. Tingkat pertumbuhan penduduk dan beban ketergantungan yang tinggi; 4. Tingkat pengangguran tinggi yang cenderung meningkat disertai kekurangan pekerjaan; 5. Sangat tergantung pada produksi pertanian dan barang ekspor; 6. Dominasi, ketergantungan dan kepekaan yang besar dalam hubungan internasional." ${ }^{14}$

Dengan demikian, apabila ingin membahas negara Indonesia terkait dinamika antara hukum dan ekonomi tidaklah lengkap tanpa mengetahui data dan fakta penyebab lahirnya dinamika tersebut, maka berikut ini adalah data dan fakta tentang Indonesia sebagai negara berkembang.

\section{Data dan Fakta tentang Indonesia sebagai Negara Berkembang.}

Kategorisasi Indonesia sebagai negara berkembang dapat ditelusuri dari data statistik Indonesia yang dirilis dalam World Development Indicators (WDI) 2012 hingga WDI 2016. Dalam data statistik yang dirilis pada tahun 2012, pendapatan Negara Indonesia masih termasuk dalam golongan menengah ke bawah bersama India dan Iraq, ${ }^{15}$ dengan pendapatan perkapita 4200 USD yang menempati ranking 148 dunia. ${ }^{16}$ Sementara itu, ketergantungan terhadap produksi pertanian masih tinggi mengingat

12 Tamanaha sebagaimana di kutip dalam Herlambang P. Wiratraman, "Penelitian Sosio Legal dan Konsekuensi Metodologisnya", https://herlambangperdana.files.wordpress.com/2008/06/penelitian-sosio-legal-dalam-tun. pdf (diakses 27 November 2017), hlm. 1.

13 Peter Mahmud Marzuki, Penelitian Hukum, Cet. I (Jakarta: Kencana, 2005), hlm. 93-96.

14 Michael P. Todaro, Op. Cit, hlm. 28.

15 Development Data Group, World Development Indicators 2012, (Wasington D.C: The World Bank, 2012), hlm. 2.

16 Ibid, hlm. 21 
perbandingan jumlah pekerja dalam bidang pertanian dengan pekerja industri sebesar 77 $\%$ berbanding $37 \%$ atau $(2: 1),{ }^{17}$ dengan tingkat pengangguran berdasarkan pendidikan, antara lain: pendidikan dasar $43,4 \%$, pendidikan menengah $40,6 \%$ dan pendidikan tinggi $10,2 \% .{ }^{18}$

Pada perkembangan selanjutnya, hingga tahun 2017. Berdasarkan data statistik dalam WDI yang dirilis pada tahun 2016, pendapatan Indonesia masih termasuk dalam golongan menengah bersama India dan Iran dengan pendapatan perkapita 10.190 USD atau naik $243 \%$ dari tahun 2012. ${ }^{19}$ Kemudian berdasarkan data yang dirilis pada Februari 2017 pendapatan perkapita naik menjadi 10.700 USD atau naik 3,5 \% dari data pada tahun 2016, dengan pertumbuhan ekonomi sebesar $5 \%{ }^{20}$ Sementara itu ketergantungan terhadap produksi pertanian juga masih tinggi mengingat perbandingan jumlah pekerja dalam bidang pertanian sebesar $65,3 \%$ berbanding 42 $\%$ atau $(1,5: 1)$ dengan pekerja industri, ${ }^{21}$ dengan tingkat pengangguran berdasarkan pendidikan, antara lain: pendidikan dasar $4,9 \%$, pendidikan menengah $10,1 \%$ dan pendidikan tinggi 5,6 \%. ${ }^{22}$

Kemudian seperti yang dilansir oleh United Nation Development Programme (UNDP) dalam Human Development Report (HDR) 2013 Indonesia Indicate \& Data dan HDR 2016 Indonesia Indicate \& Data, terlihat ketimpangan dan ketidakcocokan data. Ketimpangan dan ketidakcocokan data tersebut dapat dilihat dari perbedaan data Gross National Income (GNI), HDI value dan lainnya. Contoh dalam data yang dirilis pada tahun 2013, GNI Indonesia pada tahun 1990 adalah 1,911 USD, namun pada data yang dirilis pada tahun 2016, GNI Indonesia pada tahun 1990 adalah 4,270 USD. Kemudian pada HDI value tahun 2012, pada data HDR 2013 adalah 0,629, namun pada data HDR 2016 HDI value Indonesia pada tahun tersebut adalah $0,677 .{ }^{23}$

Tabel C.1 Data Human Development Report Indonesia 2013

\begin{tabular}{|c|c|c|c|c|c|}
\hline & $\begin{array}{c}\text { Life } \\
\text { expectancy } \\
\text { at birth }\end{array}$ & $\begin{array}{l}\text { Expected } \\
\text { years of } \\
\text { schooling }\end{array}$ & $\begin{array}{c}\text { Mean } \\
\text { years of } \\
\text { schooling }\end{array}$ & $\begin{array}{c}\text { GNI per } \\
\text { capita } \\
\text { (2005 } \\
\text { PPP\$) }\end{array}$ & $\begin{array}{l}\text { HDI } \\
\text { value }\end{array}$ \\
\hline 1980 & 57.6 & 8.3 & 3.1 & 1.278 & 0.422 \\
\hline 1985 & 60 & 9.3 & 3.5 & 1.478 & 0.456 \\
\hline 1990 & 62.1 & 9.9 & 3.3 & 1.911 & 0.479 \\
\hline 1995 & 64 & 9.9 & 4.2 & 2.630 & 0.525 \\
\hline 2000 & 65.7 & 10.3 & 4.8 & 2,390 & 0.540 \\
\hline 2005 & 67.1 & 11.2 & 5.3 & 2.950 & 0.575 \\
\hline 2010 & 68.9 & 12.9 & 5.8 & 3,775 & 0.620 \\
\hline 2011 & 69.4 & 12.9 & 5.8 & 3.973 & 0.624 \\
\hline 2012 & 69.8 & 12.9 & 5.8 & 4,154 & 0.629 \\
\hline
\end{tabular}

Sumber: Human Development Report 2013, Explanatory note on 2013 HDR composite indices Indonesia (United Nation Development Programme).

7 Ibid, hlm. 51.

18 Ibid, hlm. 59.

19 Development Data Group, World Development Indicators 2016, (Washington D.C: The World Bank, 2016), hlm. 49.

20 World Development Indicators: Size of the Economy 1.1, last updated date 02/01/2017, p. 2 or wdi.worldbank.org/ table/1.1 (diakses 23 Februari 2017) or wdi.worldbank.org/table/WV.1 (diakses 14 Agustus 2017).

21 Development Data Group, World Development Report 2016. Loc. Cit., hlm. 79 see also wdi.worldbank.org/ table/2.3\# (diakses 14 Agustus 2017).

22 Loc. Cit., hlm. 79. Lihat juga wdi.worldbank.org/table/2.5\# (diakses 14 Agustus 2017).

23 Human Development Report 2013, The Rise of the South: Human Progress in a Diverse World, Explanatory note on 2013 HDR composite indices; Indonesia, HDI values and rank changes in the 2013 Human Development Report (United Nation Development Programme), hlm. 2-5. Lihat juga Human Development Report 2016, Human Development for Everyone, Breifing Note for Countries on The 2016 Human Development Report Indonesia, (United Nation Development Programme), hlm. 2-7. 
Tabel C.2 Data Human Development Report Indonesia 2016

\begin{tabular}{cccccc}
\hline $\begin{array}{c}\text { Life } \\
\text { expectancy } \\
\text { at birth }\end{array}$ & $\begin{array}{c}\text { Expected } \\
\text { years of } \\
\text { schooling }\end{array}$ & $\begin{array}{c}\text { Mean } \\
\text { years of } \\
\text { schooling }\end{array}$ & $\begin{array}{c}\text { GNI per } \\
\text { capita } \\
(2011 \\
\text { PPP\$) }\end{array}$ & $\begin{array}{c}\text { HDI } \\
\text { value }\end{array}$ \\
\hline 1990 & 63.3 & 10.1 & 3.3 & 4,270 & 0.528 \\
\hline 1995 & 65.0 & 10.1 & 4.2 & 5,844 & 0.564 \\
\hline 2000 & 66.3 & 10.6 & 6.7 & 5,243 & 0.604 \\
\hline 2005 & 67.2 & 10.9 & 7.4 & 6,495 & 0.632 \\
\hline 2010 & 68.1 & 12.3 & 7.4 & 8,234 & 0.662 \\
\hline 2011 & 68.3 & 12.6 & 7.5 & 8,607 & 0.669 \\
\hline 2012 & 68.5 & 12.9 & 7.6 & 9,017 & 0.677 \\
\hline 2013 & 68.7 & 12.9 & 7.8 & 9,392 & 0.682 \\
\hline 2014 & 68.9 & 12.9 & 7.9 & 9,703 & 0.686 \\
\hline 2015 & 69.1 & 12.9 & 7.9 & 10,053 & 0.689 \\
\hline
\end{tabular}

Sumber: Human Development Report 2016, Human Development for Every one, Breifing Note for Countries on The 2016 Human Development Report Indonesia, (United Nation Development Programme).

Meskipun demikian, pada data tahun 2013 maupun 2016 nilai HDI Indonesia cenderung mengalami peningkatan, dengan peningkatan tahunan rata-rata sekitar $0,5 \%$ atau $0,7 \%$. Nilai HDI Indonesia untuk tahun 2012 sebesar 0,629 atau 0,677 meningkat 0,150 atau 0,149 dari tahun 1990 yang sebesar 0,479 atau 0,528. Menurut data HDR 2013, dalam kategori pengembangan manusia Indonesia berada di posisi negara menengah pada peringkat 121 dari 187 negara, naik 3 peringkat dari yang sebelumnya di peringkat 124 pada tahun 2011. Kemudian menurut HDR tahun 2016 Indonesia berada di posisi negara menengah pada peringkat 113 (medium human development) dari 188 negara. Kemudian mengenai angka harapan hidup antara tahun 1980 hingga 2012 atau antara tahun 1990 hingga 2016, harapan hidup di Indonesia saat lahir meningkat sebesar 12,2 tahun atau 5,8 tahun, dengan rata-rata tahun sekolah meningkat sebesar 2,7 tahun atau 4,6 tahun dan diharapkan tahun bersekolah meningkat sebesar 4,6 tahun atau 2,8 tahun. Hal ini di imbangi dengan peningkatan pendapatan (Gross National Income (GNI)) per kapita sebesar 10,053 US Dollar (menurut data HDR 2016). ${ }^{24}$

Dalam menyikapi laporan Bank Dunia dan HDI di atas, Sritua Arief berpendapat, bahwa data-data di atas tidak merepresentasikan data sebenarnya mengenai Indonesia secara valid dan sahih, ia mempertanyakan profesionalitas Bank Dunia karena Bank Dunia menerima begitu saja data dari Badan Pusat Statistik (BPS) tanpa adanya verifikasi terkait realitas yang sebenarnya terjadi di Indonesia dengan berbagai dinamikanya. Sanjungan dunia akan peningkatan ekonomi Indonesia hanyalah fatamorgana, karena sebenarnya Indonesia dianggap sebagai penyumbang terbesar kekayaan mereka. Dalam hal ini ia berpendapat bahwa kita seharusnya berfikir bila ekonomi kita mengalami peningkatan (surplus) mengapa harus repot mengurangi subsidi karena takut devisit anggaran negara? Kemana keuntungan tersebut mengalir? Karena dalam realitanya hasil kekayaan atau surplus dalam ekonomi tersebut mengalir ke mereka yang ada di belahan bumi barat-utara. Paradigma Bank Dunia mengenai pertumbuhan dalam teori pembangunan telah menjadi berhala baru yang mengabaikan etika, humanity, ekologi, dan lainnya sehingga menggendalikan segala aspek dan lini kehidupan di berbagai negara. Dalam 
berbagai propagandanya, Bank Dunia sebagai akar neo liberalisme mengatakan bahwa pasar bebas dan ekonomi ortodok mampu mengentaskan kemiskinan namun kenyataannya jurang pemisah antara si miskin dan si kaya semakin lebar dan perbedaan pendapatan negara maju dengan negara berkembang yang pada tahun 1948 dalam perbandingan 10:1, namun pada tahun 1989 menjadi 60:1. Bank Dunia dalam berbagai kebijakan dan rekomendasinya terkait negara berkembang tidak sedikitpun mengungkap kenyataan yang ada mengenai kerusakan lingkungan, meningkatnya kesenjangan sosial, merosotnya kualitas hidup, menumpuknya hutang luar negeri yang membuat sebuah negara mengalami ketergantungan dan tersandera secara ekonomi politik terkait kebijakan-kebijakan mereka di dalam dan luar negeri, khususnya Indonesia. ${ }^{25}$

Sejalan dengan pendapat di atas, menurut Saiful Arif, data dan fakta dari Bank Dunia mengenai perkembangan dan perekonomian Indonesia hanya merupakan fatamorgana yang semu. Karena dalam kenyataannya pertumbuhan ekonomi tersebut tidak berbasis pada realitas yang ada, kekayaan lebih banyak mengalir ke luar negeri dan hanya dinikmati oleh segelintir kelompok tertentu saja, dan seterusnya. Dimana diperkirakan $80 \%$ - 90 $\%$ aset nasional dikuasai oleh $1 \%$ penduduk dari total 258,7 juta jiwa penduduk Indonesia, gabungan BUMN dan Usaha Kecil dan Menengah (UKM) hanya menguasai $20 \%-30$ $\%$ aset perekonomian sementara $\pm 70 \%$ aset lainnya dikuasai oleh swasta, adanya penduduk berpenghasilan rata-rata Rp. 400.000,-,/ bulan, dan lainnya. Dan pernyataan mengenai semunya perkembangan dan perekonomian Indonesia tersebut terbukti dengan terpuruknya perekonomian Indonesia pada tahun 19981999 hingga hampir bangkrut, di mana justru pada masa-masa sebelumnya, dari tahun 1969 hingga tahun 1997 pertumbuhan perekonomian Indonesia mencapai rata-rata 7-8 \% pertahun, bahkan disebut oleh Bank Dunia sebagai "The Asian Miracle". ${ }^{26}$

\section{Dinamika dan Korelasi antara Ekonomi dan Hukum.}

Dalam sejarah awal mula pekembangannya hingga saat ini, kapitalisme lebih menggunakan pendekatan ilmiah atau scientific approach seperti penggunaan teori pembangunan atau "Development Theory" yang dipelopori oleh Herry S. Trumen. Dalam sejarah awal mula penerapannya, teori pembangunan atau development theory yang dipelopori oleh Herry S. Trumen merupakan siasat baru yang diterapkan oleh kapitaslisme barat yang bertujuan untuk mengganti sistem ekonomi sosialis-Uni Soviet yang runtuh, dan sekaligus untuk membendung pengaruh semangat anti

25 Menurut laporan Direktorat Jenderal Pengendalian Pencemaran dan Kerusakan Lingkungan, Kementerian Lingkungan Hidup dan Kehutanan, pada tahun 2015 hampir 68\% mutu air sungai di seluruh Indonesia dalam status tercemar berat karena limbah domestik atau rumah tangga. Sritua Arief, Pembangunanisme dan Ekonomi Indonesia Pemberdayaan Rakyat dalam Arus Globalisasi, (Jakarta: Zaman, 1997), hlm. 33-100. Lihat juga Tim Penyusun, Atlas Status Mutu Air Indonesia Tahun 2015, (Jakarta : Direktorat Jenderal Pengendalian Pencemaran dan Kerusakan Lingkungan, Kementerian Lingkungan Hidup dan Kehutanan, 2015), hlm.1-12.

26 Saiful Arif, Menolak Pembangunisme, (Yogyakarta : Pustaka Pelajar, 2000), hlm. 223-225. Lihat juga Tim Penyusun, Statistik Indonesia; Statistical Year Book of Indonesia 2017, (Jakarta: Badan Pusat Statistik, 2017), hlm. 83 dan 119. 
kapitalisme dari negara-negara berkembang. ${ }^{27}$ Hal tersebut dinilai berhasil dengan masuknya beberapa negara dengan sistem ekonomi sosialis dalam lingkaran sistem ekonomi kapitalis, seperti halnya China dan Indonesia di era Presiden Soekarno.

Dalam sejarahnya, penerapan sistem kapitalis-neo liberalis di Indonesia tidak lepas dari semangat orde baru untuk mengangkat martabat dan perekonomian bangsa dari keterpurukan selepas pemberontakan 1965, yang dalam aplikasinya diwujudkan dalam Pelita (Pembangunan Lima Tahun) yang merupakan realisasi dan implementasi dari 5 (lima) tahap Teori Rostow yang meliputi: masyarakat tradisional (The Traditional Society), prakondisi tinggal landas (The Pre-Conditions for TakeOff), masyarakat tinggal landas (The Take-Off), menuju kedewasaan (The Drive to Maturity), masa konsumsi tingkat tinggi (The Age of High Mass Consumption). ${ }^{28}$ Pengaruh dari kebijakan ini terhadap bidang hukum, ialah dengan diterapkannya Teori Hukum Pembangunan Mochtar Kusumaatmadja dalam background peraturan perundang-undangan yang ada sejak tahun 1970 ketika menjabat sebagai Menteri Kehakiman. ${ }^{29}$ Sehingga walaupun tidak dicantumkan lagi pada rencana pembangunan jangka menengah dan rencana pembangunan jangka panjang nasional tahun 2009-2014. Namun darimasa orde baru hingga era reformasi, unsur kepentingan ekonomi di hampir seluruh substansi produk hukum sangatlah kental. Sehingga pengaruh teori hukum pembangunan sebagai unsur pendukung kepentingan ekonomi dalam substansi produk hukum yang ada masih bisa dirasakan hingga sekarang. ${ }^{30}$

Terkait kajian mengenai teori dan realitas, suatu teori akan terlahir kembali dalam suatu bentuk atau transform yang baru terkait dengan kenyataanya. ${ }^{31}$ Dalam hal ini suatu teori hukum terkait dengan realitasnya akan bertranformasi

Mansour Fakih, Runtuhnya Teori Pembangunan dan Globalisasi, (Yogyakarta: Pustaka Pelajar, 2012), hlm. 200.

28 W.W. Rostow, "The Stage of Economic Growth," Jstor Journal The Economic History Review, Second Series, Vol. 12, No. 1 (1959): 4-13.

29 Menurut Romli Atmasasmita, prinsip dan ajaran inti dari Teori Hukum Pembangunan Mochtar Kusumaatmadja, antara lain sebagai berikut:

a. Semua masyarakat yang sedang membangun selalu dicirikan dengan perubahan dan hukum berfungsi sebagai penjamin perubahan dengan cara teratur yang dibantu oleh peraturan perundang-undangan atau keputusan pengadilan atau kombinasi keduanya dan Mochtar menolak perubahan yang tidak teratur menggunakan kekerasan semata.

b. Baik perubahan dan ketertiban keteraturan merupakan tujuan awal dari masyarakat yang sedang membangun dan hukum berfungsi sebagai sarana yang tidak dapat diabaikan dalam pembangunan.

c. Fungsi hukum dalam masyarakat adalah menjamin ketertiban melalui kepastian hukum sekaligus berfungsi sebagai pembantu, pengatur proses perubahan.

d. Hukum yang baik ialah hukum yang sesuai dengan norma atau kaidah yang hidup dalam masyarakat.

e. Hal ini hanya dapat diimplementasikan oleh suatu kekuasaan tapi sekaligus menjadi rambu-rambu bagi kekuasaan tersebut.

Lihat Romli Atmasasmita, Teori Hukum Integratif Rekonstruksi terhadap Teori Hukum Pembangunan dan Teori Hukum Progresif, Cet. I, (Yogyakarta; Genta Publishing, 2012), hlm. 60, 65-66.

30 Perlu diperhatikan bahwa situasi seperti yang kita ketahui dari penjelasan di atas, bukanlah tanpa alasan, yaitu karena terjeratnya Indonesia dalam sistem IMF dan Bank Dunia serta perdagangan bebas yang tergabung dalam WTO (World Trade Organization), dan lainnya.

31 H.R. Otje Salman S. dan Anthon F. Susanto, Teori Hukum Mengingat, Mengumpulkan dan Membuka Kembali, Cet. 7 (Bandung: Refika Aditama, 2013), hlm. 30. 
dari sekedar teori diaplikasikan menjadi sebuah peraturan perundang-undangan yang mengatur segala aspek sendi kehidupan yang menghubungkan manusia dengan sesama maupun individu lebih khususnya yang terkait dengan aspek ekonomi atau perdata. Sesuai dengan fungsi dari teori sebagai alat eksplanasi, alat pengontrol, alat peramal dan alat penguji. ${ }^{32}$ Terkait hubungan antara ekonomi dan hukum modern, bukan lagi menjadi rahasia bila hukum modern (hukum positif) lebih berfungsi sebagai fasilitator atau instrumen yang memberikan kepastian hukum untuk menggerakkan roda perekonomian modern, dalam hal ini kapitalis atau neo liberalis yang merupakan bentuk baru dari imperialisme. Dan hal tersebut merupakan realitas yang terjadi di Indonesia sebagaimana diterapkannya "Teori Hukum Pembangunan" dalam substansi peraturan perundangundangan yang berlaku di Indonesia. Di mana dengan teori tersebut, berbagai peraturan perundang-undangan dalam kegiatan ekonomi di Indonesia seolah lebih berfungsi sebagai fasilitator atau instrumen dari sistem ekonomi neo liberal.

Sejarah awal mula masuknya kapitalisme ke Indonesia, yang sekarang lebih dikenal dengan istilah neo liberalisme dimulai dari terjeratnya Indonesia dalam sistem IMF dan Bank Dunia (capitalisme global system). Dan hal tersebut menjadikan pemerintah tidak punya pilihan dan semakin terperosok dalam sistem Neo Liberalisme yang semula oleh Margareth Teacher sebagai alternatif, namun malah menjadi bumerang dan buah simalakama bagi negara-negara berkembang, khususnya
Indonesia. Hal tersebut karena tidak lain menjadi sapi-sapi perah bagi sistem perekonomian kapitalis yang menguntungkan negara barat. Sehingga dalam kebijakan ekonominya selama ini, pemerintah Indonesia dari tahun 1969 terlihat mengaplikasikan paket deregulasi yang direkomendasikan oleh Bank Dunia dalam upaya untuk membuat ekonomi negara ini menjadi lebih baik. Berbagai kebijakan deregulasi World Bank yang diaplikasikan di Indonesia antara lain: "1) Intervensi pemerintah harus dihilangkan atau diminimumkan karena akan mengakibatkan distorsi pasar; 2) Liberalisasi seluruh kegiatan ekonomi dan segala bentuk proteksi harus dihilangkan; 3) Memperbesar dan memperlancar arus masuk investasi asing dengan fasilitas yang lebih luas dan longgar." ${ }^{33}$

Dalam realitasnya, terkait kebijakan pemerintah untuk menghilangkan dan meminimumkan intervensi dan proteksi pasar sangat terasa dengan diminimkannya anggaran subsidi, mulai dari penghilangan subsidi minyak tanah, pengurangan subsidi listrik, pengurangan subsidi Bahan Bakar Minyak (BBM), dan lainnya. Terkait dengan kenaikan harga BBM, suatu ketika pernah terjadi peristiwa di mana Dewan Perwakilan Rakyat (DPR) sebagai legislator yang mempunyai hak budgeting seakan tidak bisa berbuat apa-apa terkait kenaikan dan pengurangan subsidi BBM karena alasan menyelamatkan negara dari devisit anggaran dan kebangkrutan kas negara. Sementara ada pihak dari ahli ekonomi dengan data dan analisa

32 Juhaya S. Praja, Teori Hukum dan Aplikasinya, Cet. I (Bandung : Pustaka Setia, 2011), hlm. 3-4.

33 Sritua Arief, Op.Cit, hlm. 33. 
yang ia lakukan menduga, bahwa hal tersebut hanyalah rekayasa kepentingan politik belaka. ${ }^{34}$

Kemudian dalam hal kebijakan terkait mempermudah investasi asing dan liberalisasi pasar dan ekonomi yang diartikan dengan memberikan peranan yang lebih besar pada mekanisme pasar dan mengurangi intervensi pemerintah dalam kegiatan ekonomi, meskipun dinilai tidak melindungi ekonomi kerakyatan. ${ }^{35}$ Hal ini dibuktikan dengan berbagai fakta dan realitas, antara lain perjanjian internasional tentang perdagangan bebas (ACFTA) yang dipaksakan untuk disetujui, sebagai dampaknya ialah menjamurnya barang-barang import dari China di pasaran dan matinya industri kecil menengah karena kalah bersaing. Perlu diketahui, bahwa matinya industri kecil menengah disebabkan oleh beberapa faktor, antara lain ialah karena keberpihakan birokrasi dan undang-undang yang berlaku pada ekonomi kapitalis, keterbatasan modal, keterbelakangan di bidang Iptek, dan kurangnya mutu Sumber Daya Manusia (SDM) sehingga tidak mampu dan kalah bersaing dalam pasar bebas dengan pemodal yang lebih besar. ${ }^{36}$

Selain fenomena di atas, bukti lain terkait mempermudah investasi asing dan liberalisasi pasar dan ekonomi tergambar dengan jelas pada produk peraturan perundang-undangan berikut, antara lain:

1. Kriteria pemerintah mengenai istilah usaha mikro pada Pasal 6 UU No. 20 Tahun 2008 tentang Usaha Mikro, Kecil dan Menengah yang menyatakan, bahwa yang dimaksud dengan kriteria usaha mikro ialah yang mempunyai kekayaan 50 juta dengan pendapatan atau hasil penjualan 300 juta/ tahun, melihat kriteria dalam UU tersebut, sesuaikah dengan keadaan sosial masyarakat Indonesia? Maka sangatlah wajar jika para pedagang asongan, kaki lima, warung tegalan, dan lainnya yang tidak sesuai dengan kriteria tersebut terkesan tidak mendapat perlindungan hukum apalagi perlindungan pemerintah, yang justru setiap waktu mematikan mata pencaharian mereka dengan segala kebijakan-kebijakannya. Dalam pola inilah para sosiolog hukum menggugat tidak berlakunya equality before the law yang terjadi pada pihak yang lemah melawan pihak yang kuat dan berkuasa, karenanya hukum harus bersifat afirmatif, responsif terhadap hal di atas. Namun setelah bertahun-tahun perumusannya dan

34 Menurut Kwik Kian Gie: kebohongan pemerintah tentang kenaikan BBM untuk menutupi bolongnya APBN tidak berdasar karena dalam data dan analisanya, Indonesia tanpa menaikan bbm masih akan mendapat surplus 97, 955 trilyun, namun bila menaikkan BBM di kisaran Rp 6.000,00 maka akan mendapat surplus 192,455 trilyun, sementara BLSM hanyalah politisasi untuk menaikkan citra dan menguntungkan pihak tertentu sebagaimana kebijakan pada tahun 2009. Kebijakan ini sesuai dengan aspirasi UU No. 22 Tahun 2001 tentang Minyak dan Gas Bumi yang menghendaki supaya rakyat Indonesia merasa dan berpikir bahwa dengan sendirinya kita harus membayar bensin dengan harga dunia, situasi demikian dibuat dengan pertimbangan agar semua perusahaan minyak asing bisa memperoleh laba dengan menjual bensinnya di Indonesia. http://kwikkiangie.com/ v1/2012/03/kontroversi-kenaikan-harga-bbm (diakses 24 Juni 2013).

35 Moeljarto Tjokrowinoto, Pembangunan Dilema dan Tantangan, Cet. I (Yogyakarta: Pustaka Pelajar, 2012), hlm. 229.

36 Kesimpulan ini didasarkan akan faktor-faktor yang harus ingin diperbaiki pemerintah melalui MP3EI-nya. Lihat Kementerian Koordinator Bidang Perekonomian, Masterplan Percepatan dan Perluasan Pembangunan Ekonomi Indonesia, ed. Deputi Bidang Infrastruktur dan Pengembangan Wilayah Kementerian Koordinator Bidang Perekonomian, Cet. I (Jakarta: Kementerian Koordinator Bidang Perekonomian, 2011). 
aplikasinya ke dalam undang-undang, dalam realita yang ada pemilik modal atau yang kuatlah yang menang.

2. Batas maksimal kepemilikan modal asing dalam Perpres No. 111 Tahun 2007 tentang Daftar Bidang Usaha yang Tertutup dan Bidang Usaha yang Terbuka dengan Persyaratan di Bidang Penanaman Modal. Dalam subtansinya, Peraturan Presiden tersebut dianggap sebagai bentuk peraturan perundang-undangan yang sarat dengan kepentingan kapitalis. Hal ini terlihat dalam lampirannya, di mana pada sektor-sektor vital seperti dalam bidang pengelolaan hasil bumi (perminyakan, pertambangan, pertanian, perkebunan), energi listrik, jasa keuangan perbankan, sistem komunikasi, dan lainnya, batas kepemilikan modal asing dapat mencapai 90\% hingga 99\% dari keseluruhan modal. ${ }^{36}$ sehingga dengan adanya Perpres ini, semua sektor vital kehidupan rakyat terbuka untuk modal usaha asing yang seakan menghalalkan bentuk soft imperialism baru berlaku di Indonesia.

Contoh lainnya, yang disebabkan oleh birokrasi dan peraturan perundang-undangan yang ada terkait mempermudah investasi asing dan liberalisasi pasar dan ekonomi, ialah dengan menjamurnya supermarket dari daerah sampai lingkungan masyarakat terkecil sehingga mematikan usaha-usaha kecil radius tertentu. Dalam hal ini tidak berpihaknya pemerintah daerah dan lemahnya regulasi pemerintah dalam Perpres No. 112 Tahun 2007 tentang Penataan dan Pembinaan Pasar Tradisional, Pusat Perbelanjaan dan Toko Modern, semakin memperburuk keadaan. Lemahnya regulasi terkait penyerahan pengelolaannya kepada pemerintah daerah seperti yang diatur dalam Perpres No. 112 Tahun 2007 Pasal 15, membuat pemerintah daerah lebih mengejar pendapatan daerah dari pada perlindungan ekonomi rakyat mereka. Hal ini diperparah dengan substansi Perpres No. 112 Tahun 2007 Pasal 5 ayat 4, ${ }^{37}$ yang seakan ada pembiaran dan membuat celah bagi pihak-pihak tertentu karena tidak secara jelas mencantumkan jarak antar minimarket, sehingga sebagian perda-perda pemerintah daerah yang ada seakan memfasilitasi berdirinya supermarket, Alfamart, Indomart dan lainnya untuk mengejar pendapatan daerah semata.

Beberapa realitas di atas mengenai sistem peraturan perundang-undangan yang memfasilitasi sistem perekonomian yang ada, berakibat pada menjamurnya super dan minimarket merupakan cerminan terkait kebijakan yang selama ini dijalankan oleh pemerintah mengenai deregulasi pasar yang direkomendasikan oleh Bank Dunia. Meskipun masih banyak kasus lain terkait kebijakan pemerintah mengenai deregulasi, seperti UU No. 25 Tahun 2007 Pasal 22 yang tidak berlaku lagi karena judicial review oleh organisasi

36 Perpres No. 111 Tahun 2007 tentang Daftar Bidang Usaha yang Tertutup dan Bidang Usaha yang Terbuka dengan Persyaratan di Bidang Penanaman Modal, hlm. 15-37.

37 Ketentuan Pasal 5 ayat (4) Perpres No. 112 Tahun 2007 menyebutkan: "Minimarket boleh berlokasi pada setiap sistem jaringan jalan, termasuk sistem jaringan jalan lingkungan pada kawasan pelayanan lingkungan (perumahan) di dalam kota/perkotaan". 
masyarakat. ${ }^{38}$ Fenomena PT. Freeport terkait UU No. 1 Tahun 1967 tentang Penanaman Modal Asing serta UU No. 11 Tahun 1967 tentang Ketentuan-Ketentuan Pokok Pertambangan dan lainnya.

Dengan demikian, berdasarkan penjelasan di atas, berbagai hal tersebut cukup menjadi bukti bahwa peraturan perundang-undangan yang berlaku di Indonesia cenderung memfasilitasi sistem dan pola perekonomian tertentu bahkan tunduk pada sistem perekonomian yang ada. Maka elemen taat hukum yang ada pada masyarakat tidak akan pernah dapat bekerja dengan sempurna untuk mengatur maupun mengontrol secara paksa dinamika ekonomi yang ada, sehingga tampak seakan ekonomi lebih determinan dari hukum yang mengatur ekonomi itu sendiri. Namun bila melihat peristiwa pada Mei 1998 dan kenyataan yang diangkat John Perkins dalam bukunya "Confessions of an Economic Hit Man" tentang Indonesia, telah menjelaskan terkait dinamika antara ekonomi dan hukum tidak hanya selalu pada determinasi ekonomi atas hukum melainkan dapat juga sebaliknya karena ekonomi modern membutuhkan unsur kepastian hukum dan kestabilan sosial politik untuk menjalankan roda perekonomian, dengan demikian hukum terkadang terlihat lebih determinan dari ekonomi.

Terkait dinamika antara hukum dan ekonomi sebagaimana telah dijelaskan, R. Pound dalam bukunya "An Introduction of The Philosophy of Law" pernah menerangkan, bahwa konsep hukum dalam realismenya dapat dimaknai sebagai jawaban atas tuntutan hukum ekonomi dan hukum sosial yang menghargai seseorang dalam masyarakat, dan dapat juga dimaknai sebagai perangkat sistem norma yang diberlakukan terhadap manusia dalam masyarakat oleh kelas masyarakat yang berkuasa untuk kepentingan kelas yang berkuasa. ${ }^{39}$ Dua makna hukum Pound tersebut merupakan acuan bagaimana memahami dan menyikapi fungsi hukum dalam pembangunan masyarakat dan peran ilmu-ilmu sosial dalam membantu perkembangan ilmu hukum. Dalam hal ini Pound yang mengikuti aliran instrumentalisme hukum, beranggapan bahwa dalam realitasnya, hukum dipengaruhi oleh tekanan sosial, faktor politik dan ekonomi.

Mengenai gambaran dinamika antara hukum dan ekonomi di atas, juga menjelaskan betapa kuatnya pengaruh kebutuhan dasar manusia dalam ekonomi, mengalahkan kebutuhan dasar akan rasa aman dan ketertiban. Secara konseptual, dinamika di atas pada dasarnya mengerucut pada satu pola pokok bahwa manusia hidup bukan tanpa tujuan. Di mana dalam mencapai tujuannya, tentu sangatlah erat kaitannya dengan desire atau hasrat keinginan. David C. Mcclelland dalam bukunya "Achieving Society" menjelaskan, bahwa dalam hasrat keinginan manusia tersimpan sebuah kekuatan, hasrat merupakan jenis kekuatan yang bersifat mendorong yang sering bertentangan dengan

38 Terkait dengan UU No. 25 Tahun 2007 tentang Penanaman Modal Pasal 22 yang menyatakan "kemudahan pelayanan dan/atau perizinan hak atas tanah sebagaimana dimaksud dalam Pasal 21 huruf a dapat diberikan dan diperpanjang di muka sekaligus dan dapat diperbarui kembali atas permohonan penanam modal", dinilai sebagai bentuk keberpihakan pemerintah kepada modal asing karena dapat mengakomodir kepentingan pihak asing untuk menguasai sektor strategis seperti pertambangan dan kehutanan. Lihat Saut P. Panjaitan, "Politik Pembangunan Hukum di Bidang Investasi, Suatu Keniscayaan Konstitusi Ekonomi”, Jurnal Konstitusi, Vol. 7, No. 2, April (2010): 60-61.

39 R. Pound, An Introduction of The Philosophy of Law, dalam Romli Atmasasmita, Op.Cit, hlm. 70. 
alasan akan tetapi pada akhirnya selalu dikontrol oleh alasan tersebut. ${ }^{40}$ Seperti halnya mengenai kebutuhan jasmani yang selalu ingin dikontrol namun bila tak terpenuhi maka justru akan mengontrol, seperti ketika lapar, maka akan mudah marah dan sebagainya. Hasrat yang dalam istilah lain disebut juga dengan motivasi telah banyak menjadi bahan kajian para ahli psikologi, namun tidak hanya digunakan pada disiplin ilmu psikologi saja. Dalam aplikasinya, teori tentang motivasi bisa diaplikasikan dalam berbagai bidang disiplin ilmu sosial, misalnya untuk menjelaskan fenomena yang sedang terjadi dalam bidang ekonomi, politik, sosiologi dan lainnya. Salah satu teori motivasi tersebut yang masih relevan hingga sekarang, ialah teori motivasi Abraham Maslow. Dalam teori Abraham Maslow, ia membagi motivasi manusia menjadi 5 (lima) tingkatan hierarki kebutuhan yang digambarkan dalam bentuk segitiga berikut:

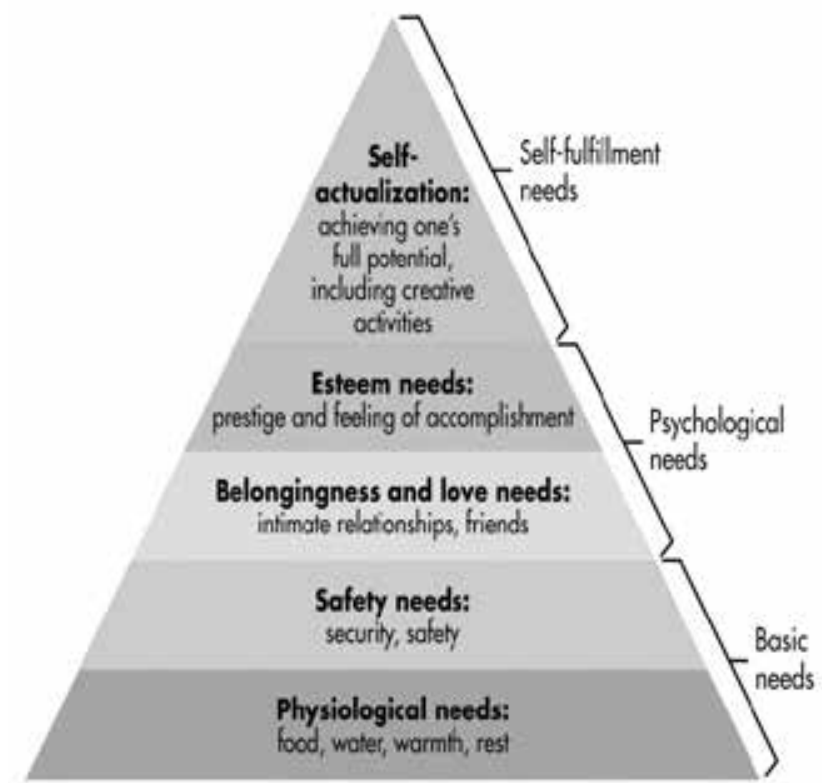

Gambar: 5 (lima) tingkatan hierarki kebutuhan menurut Abraham Maslow
Berdasarkan hierarki di atas, dapat ketahui bahwa kebutuhan fisik biologis dan rasa aman sama-sama merupakan kebutuhan dasar bagi manusia. Sehingga karena korelasi keduanya sebagai basic needs, maka sangatlah wajar bila terjadi tumpang tindih antara hukum dan ekonomi. Maka dari itu, dalam hal ini teori Abraham Maslow dapat memberikan jawaban dan gambaran akan fenomena yang terjadi mengenai determinasi ekonomi atas hukum dan sebaliknya yang terjadi di suatu negara. ${ }^{41}$

Berdasarkan penjelasan di atas, terlihat bahwa dampak atau implikasi dari sistem kapitalisme dan teori hukum pembangunan terhadap peraturan perundang-undangan yang berlaku di Indonesia mempunyai sisi negatif sekaligus positif, dampak positif antara lain: 1) Segala kebijakan pemerintah yang diberlakukan berdasarkan peraturan perundang-undangan yang berlaku; 2) Terjaminnya unsur kepastian hukum di setiap perubahan yang ada; dan 3) Hukum berjalan searah dengan pembangunan ekonomi sehingga tidak menghambat perekonomian negara.

Sedangkan dampak negatif dari implikasi tersebut antara lain: 1) Hukum sering digunakan sebagai legalitas dan/atau sarana kotor untuk memaksakan suatu kehendak yang menguntungkan kepentingan pihak tertentu dan merugikan orang banyak; 2) Hukum lebih dianggap sebagai instrumen pendukung sistem ekonomi, sehingga mengakibatkan ekonomi lebih determinan atas hukum; 3) Rusaknya sistem hukum karena hukum menjadi tidak berdaya bila dihadapkan pada tatanan ekonomi yang menjadi basic need kehidupan manusia

40 David C. Mc. Clelland, Achieving Society, dalam Alex Sobur, Psikologi Umum dalam Lintasan Sejarah, Cet. II,(Bandung: Pustaka Setia, 2009), hlm. 263.

41 Alex Sobur, Psikologi, Op. Cit., hlm. 273. 
disamping kebutuhan akan rasa keamanan, keadilan dan ketertiban, yang terabaikan dengan kebutuhan ekonomi; 4) Menurunnya kesadaran dan ketaatan masyarakat terhadap hukum (peraturan perundang-undangan) yang berlaku, yang disebabkan oleh penerapannya yang dipaksakan, tidak adil, merugikan kepentingan umum serta tidak sesuai dengan norma yang hidup dan berlaku dalam suatu masyarakat.

Meskipun demikian, mulai dari tahun 2016 kebijakan pemerintah terkait dinamika antara hukum dan ekonomi mulai berubah. Hal tersebut ditandai dengan direvisinya Perpres No. 111 Tahun 2007 digantikan Perpres No. 44 Tahun 2016 tentang Daftar Bidang Usaha yang Tertutup dan Bidang Usaha yang Terbuka dengan Persyaratan di Bidang Penanaman Modal. Hal tersebut terlihat di dalam lampirannya, di mana dalam sektor-sektor vital seperti dalam bidang pengelolaan hasil bumi (perminyakan, pertambangan, pertanian, perkebunan), energi listrik, jasa keuangan perbankan, sistem komunikasi dan lainnya, terbagi-bagi dalam kriteria dan kebijakan tertentu, walaupun batas kepemilikan modal asing masih dapat mencapai 90\% hingga 99\% dari keseluruhan modal. Contoh: jasa pengeboran migas di darat (onshore oil) harus $100 \%$ modal dalam negeri, di mana sebelumnya pada tahun 2007 modal asing dapat mencapai $95 \%$, pembangkit tenaga listrik skala tertentu harus $100 \%$ modal dalam negeri atau maksimal $49 \%$ atau $67 \%$ modal asing, di mana sebelumnya pada tahun 2007 tanpa kriteria tertentu modal asing dapat mencapai $95 \%$, dan lainnya. ${ }^{42}$

Berdasarkan pembahasan di atas, terlihat bahwa berbagai kebijakan baru pada peraturan perundang-undangan tahun 2016 tersebut mengaplikasikan pendapat Sunaryati Hartono mengenai hukum ekonomi, di mana dalam pengertian dan aplikasinya hukum ekonomi terbagi menjadi pengertian hukum ekonomi pembangunan dan hukum ekonomi sosial, di mana hukum ekonomi sosial antara lain menyangkut regulasi dan kebijakan hukum mengenai pemerataan pembangunan ekonomi secara adil sesuai dengan harkat dan martabat bangsa Indonesia. ${ }^{43}$ Selain itu, kebijakan tersebut terlihat merupakan upaya pemerintah dalam mengimplementasikan UUD NRI Tahun 1945 Pasal $33^{44}$ dan Sila ke-5 dari Pancasila.

Berdasarkan berbagai pembahasan di atas, tidak dapat dipungkiri bahwa era global menjadikan globalisasi neo liberalisme kapitalisme sebagai dasar kebijakan sistem perekonomian di suatu masa, telah mempengaruhi kebijakan pemerintah dalam merancang, membuat dan mengesahkan peraturan perundang-undangan yang ada. Fenomena ini secara tidak langsung telah menjadikan globalisasi mencapai tahap globalisasi sebagai ideologi, hal tersebut tercermin pada realitas kepentingan swasta yang melebihi kepentingan publik, persaingan dengan segala resikonya dan memperlakukan segala sesuatu sebagai komoditas, membuktikan

42 Perpres No. 44 Tahun 2016 tentang Daftar Bidang Usaha yang Tertutup dan Bidang Usaha yang Terbuka dengan Persyaratan di Bidang Penanaman Modal, hlm. 15-39.

43 Sunaryati Hartono dalam Candra Irawan, Dasar-Dasar Pemikiran Hukum Ekonomi Indonesia, (Bandung: CV. Mandar Maju), hlm. 8-9.

44 Ketentuan Pasal 33 Undang-Undang Dasar NRI Tahun 1945 menyebutkan: "Bumi dan air dan kekayaan alam yang terkandung di dalamnya dikuasai oleh negara dan dipergunakan untuk sebesar-besarnya kemakmuran rakyat." 
dampak negatif dari proses globalisasi neo liberalisme ala kapitalis dalam tatanan sosial.

Dengan demikian antara hukum dan ekonomi terdapat korelasi yang sangat erat kaitannya dalam tatanan sosial kemasyarakatan kenegaraan. Dalam hal ini determinasi ekonomi atas hukum lebih merusak sistem sosial kemasyarakatan dari pada determinasi hukum atas ekonomi. Selain merusak hukum dan tatanan sosial, determinasi ekonomi juga telah merusak unsur manusia dan kemanusiaan sebagai unsur terpenting dari semua elemen sosial, karena rusaknya moral attitude manusia adalah awal dan biang dari segala kerusakan tatanan sosial termasuk hukum.

\section{Penutup}

Berdasarkan pembahasan di atas dapat disimpulkan, bahwa dinamika antara hukum dan ekonomi yang tengah terjadi di Indonesia selalu tergambar dan tercermin dalam determinasi ekonomi atas hukum dan sebaliknya. Determinasi ekonomi atas hukum dan sebaliknya dapat dilihat dalam dua pola: Pertama, dinamika antara hukum dan ekonomi terkait untung rugi kadang menjadikan undangundang atau hukum yang ada tidak berlaku atau diabaikan "lawless", karena tuntutan ekonomi lebih diutamakan dari pada penegakan hukum yang merugikan kepentingan ekonomi. Kedua, hukum (peraturan perundang-undangan) hadir untuk menjamin dan memfasilitasi sistem ekonomi yang ada, dalam hal ini terkait kegiatan ekonomi tidak dapat dilakukan tanpa adanya situasi atau keadaan yang kondusif, maka hukum dalam bentuk peraturan perundangundangan hadir untuk menjamin kepastian hukum tersebut dan dari pola kedua inilah hukum kadang lebih determinan atas ekonomi. Selain itu, berdasarkan data serta fakta yang disajikan pada pembahasan di atas juga dapat disimpulkan, bahwa peraturan perundangundangan yang berlaku di Indonesia pada masa pemerintahan tertentu memang cenderung memfasilitasi sistem dan pola perekonomian tertentu, bahkan cenderung tunduk pada sistem perekonomian yang ada.

Disarankan sebagai upaya mencapai welfare state, hendaknya setiap kebijakan di bidang hukum yang digunakan untuk setiap kegiatan ekonomi dikembalikan dan didasarkan atas nilai-nilai yang terkandung dalam Pancasila dan didasarkan pula pada konstitusi yang berlaku.

\section{Daftar Pustaka}

\section{Buku}

Arif, Saiful, Menolak Pembangunanisme, (Yogyakarta : Pustaka Pelajar, 2000)

Arief, Sritua, Pembangunanisme dan Ekonomi Indonesia Pemberdayaan Rakyat dalam Arus Globalisasi, (Jakarta: Zaman, 1997)

Atmasasmita, Romli, Teori Hukum Integratif Rekonstruksi Terhadap Teori Hukum Pembangunan dan Teori Hukum Progresif, Cet. I (Yogyakarta: Genta Publishing, 2012)

Fakih, Mansour, Runtuhnya Teori Pembangunan dan Globalisasi, (Yogyakarta: Pustaka Pelajar, 2012)

H.R. Otje Salman S. dan Anthon F. Susanto, Teori Hukum Mengingat, Mengumpulkan dan Membuka Kembali, Cet. VII (Bandung: Refika Aditama, 2013)

Irawan, Candra, Dasar-Dasar Pemikiran Hukum Ekonomi Indonesia, (Bandung: CV. Mandar Maju, 2016)

Kementerian Koordinator Bidang Perekonomian, Masterplan Percepatan dan Perluasan Pembangunan Ekonomi Indonesia (MP3EI), Cet. I (Jakarta: Kementerian Koordinator Bidang Perekonomian, 2011)

Lyndolp, Paul E., Geography of the U.S.S.R. 5th Ed. Elkhart Lake, (Wisconsin: Misty Valley Publishing, 1990)

Marzuki, Peter Mahmud, Penelitian Hukum, Cet. I (Jakarta: Kencana, 2005)

Praja, Juhaya S., Teori Hukum dan Aplikasinya, Cet. I (Bandung : Pustaka Setia, 2011) 
Sobur, Alex, Psikologi Umum dalam Lintasan Sejarah, Cet. II (Bandung: Pustaka Setia, 2009)

Tjokrowinoto, Moeljarto, Pembangunan Dilema dan Tantangan, Cet. I (Yogyakarta: Pustaka Pelajar, 2012)

Todaro, Michael P, Pembangunan Ekonomi di Dunia Ketiga, diterjemahkan oleh Burhanuddin Abdullah dan Harris Munandar, Cet. II (Surabaya: Penerbit Erlangga, 1989)

\section{Artikel/Jurnal/Hasil Penelitian}

Bureau of the Census, USA/USSR: Facts and Figures, Washington D.C: U.S. Government Printing Office, 1991

Development Data Group, World Development Indicators 2012, Wasington D.C: The World Bank, 2012

Development Data Group, World Development Indicators 2016, Wasington D.C: The World Bank, 2016

Human Development Report 2013, The Rise of the South: Human Progress in a Diverse World, Explanatory note on 2013 HDR composite indices Indonesia, United Nation Development Programme

Human Development Report 2016, Human Development for Every One, Breifing Note For Countries on The 2016 Human Development Report Indonesia, United Nation Development Programme

Jaworski, Taylor and Price V. Fishback, "World War II (Prepared for the Oxford Handbook of American Economic History)", March, (2014)

Kesternich, Iris et. al, "The Effects of World War II on Economic and Health Outcomes across Europe," RAND Labor and Population Working Paper Series, January 22, (2012)

Kesternich, Iris et. al,"The Effects of World War II on Economic and Health Outcomes across Europe," www.mitpressjournals.org, Vol. 96, No. 1, March, (2014)

Supriyanto, Memahami Cara Bekerja Sistem Perekonomian, (Jurnal Ekonomi \& Pendidikan, Volume 6 No. 2, November 2009)

Susan J. Linz, "World War II and Soviet Economic Growth 1940-1953," Faculty Working Paper No. 1038, Bureau of Economics and Businnes Research (BEBR), University of Illinois, May, (1984)

Panjaitan, Saut P., Politik Pembangunan Hukum di Bidang Investasi Suatu Keniscayaan Konstitusi
Ekonomi, (Jakarta: Jurnal Konstitusi, Volume 7, No. 2, April 2010)

Prasetyo, Eko, Kapitalisme \& Neoliberalisme, Sebuah Tinjauan Singkat, Ekonomi Politik, (Journal AlManar, Edisi I, 2004)

Rostow, W.W. "The Stage of Economic Growth", Jstor Journal, The Economic History Review, Second Series, Vol. 12, No. 1, (1959)

Ratnawati, Tri, Satu Dasa Warsa Pemekaran Daerah Era Reformasi: Kegagalan Otonomi Daerah?, (Jurnal Ilmu Politik, Edisi 21, 2010)

Tim Penyusun, Atlas Status Mutu Air Indonesia Tahun 2015, (Jakarta : Direktorat Jenderal Pengendalian Pencemaran dan Kerusakan Lingkungan Kementerian Lingkungan Hidup dan Kehutanan, 2015)

Tim Penyusun, Statistik Indonesia: Statistical Year Book of Indonesia 2017, (Jakarta: Badan Pusat Statistik, 2017)

Weiss, Kathryn Stoner and Michael Mcfaul, "Domestic and International Influences On The Collapse Of The Soviet Union (1991) And Russia's Initial Transition To Democracy (1993)", Cddrl Stanford Working Papers. Number: 108, Center On Democracy, Development, And The Rule Of Law: Freeman Spogli Institute For International Studies, March (2009)

\section{Internet}

Herlambang P. Wiratraman, "Penelitian Sosio Legal dan Konsekuensi Metodologisnya", https://herlambangperdana.files.wordpress. com/2008/06/penelitian-sosio-legal-dalam-tun. pdf (diakses 27 November 2017)

http://kwikkiangie.com/v1/2012/03/kontroversikenaikan-harga-bbm (diakses 24 juni 2013)

http://wdi.worldbank.org/table/2.3\# (diakses 14 Agustus 2017)

http://wdi.worldbank.org/table/2.5\# (diakses 14 Agustus 2017)

http://wdi.worldbank.org/table/1.1 (diakses 23 Februari 2017)

http://wdi.worldbank.org/table/WV.1 (diakses 14 Agustus 2017)

https://www.bps.go.id/KegiatanLain/view/id/127 (diakses 13 November 2017)

h t t p : / / region a l. kom pas.com / $\mathrm{read} / 2017 / 11 / 09 / 16473271 /$ kelompokbersenjata-di-papua-intimidasi-dan-rampasharta-warga (diakses 13 November 2017)

\section{Peraturan}


Undang-Undang Nomor 73 Tahun 1958 tentang Pemberlakuan Kembali Undang-Undang Nomor 1 Tahun 1946 tentang Kitab Undang-Undang Hukum Pidana

Undang-Undang Nomor 1 Tahun 1967 tentang Penanaman Modal Asing

Undang-Undang Nomor 11 Tahun 1967 tentang Ketentuan-Ketentuan Pokok Pertambangan

Undang-Undang Nomor 22 Tahun 2001 tentang Minyak dan Gas Bumi

Undang-Undang Nomor 25 Tahun 2007 tentang Penanaman Modal

Peraturan Presiden Nomor 111 Tahun 2007 tentang Daftar Bidang Usaha yang Tertutup dan Bidang Usaha yang Terbuka dengan Persyaratan di Bidang Penanaman Modal

Peraturan Presiden Nomor 112 Tahun 2007 tentang Penataan dan Pembinaan Pasar Tradisional, Pusat Perbelanjaan dan Toko Modern

Peraturan Presiden Nomor 44 Tahun 2016 tentang Daftar Bidang Usaha yang Tertutup dan Bidang Usaha yang Terbuka dengan Persyaratan di Bidang Penanaman Modal

Undang-Undang Nomor 20 Tahun 2008 tentang Usaha Mikro, Kecil dan Menengah 
"Halaman ini dikosongkan" 